\title{
Pemanfaatan Pangan Lokal Lele Untuk Pembuatan Nugget
}

\author{
The Utilization of Catfish as Local Food for Nugget \\ Yuniarti DR ${ }^{1}$, Diah Ratnasari ${ }^{2}$, Faris Muhammad Juldan Lababan ${ }^{3}$ \\ 1,2,3 Program Studi Ilmu Gizi, Fakultas Ilmu Kesehatan, Universitas Muhadi Setiabudi, Indonesia \\ e-mail: ${ }^{1}$ yuniartidewi.rahmawati@gmail.com, ${ }^{2}$ diahratna1708@gmail.com, ${ }^{3}$ gitd2018@gmail.com
}

\begin{abstract}
Abstrak
Budidaya yang ada di Desa Cikakak, Kecamatan Banjarharjo adalah budidaya ikan lele dengan jenis Sangkuriang. Selama ini pemanfaatan ikan lele masih terbatas, hanya dijual secara langsung kepada pemesan atau di pasarkan tanpa adanya pengolahan dan sebagai konsumsi sehari-hari. Agar dapat meningkatkan kreativitas dan nilai ekonomis lele sebagai hasil budidaya maka dilaksanakan program pengabdian masyarakat dengan sasaran Ibu PKK, kader posyandu dan pelaku usaha budidaya ikan lele Desa Cikakak. Pengabdian kepada masyarakat yang dilaksanakan adalah dengan memberikan penyuluhan tentang kandungan gizi ikan lele dan pelatihan pengolahan nugget lele bagi Ibu PKK, kader posyandu dan pelaku usaha budidaya ikan lele Desa Cikakak. Kegiatan pengabdian ini bertujuan untuk meningkatkan kreatifitas warga desa Cikakak dalam pemanfaatan ikan lele sehingga meningkatkan nilai ekonomisnya. Hasil dari pengabdian di desa Cikakak adalah adanya peningkatan pengetahuan tentang kandungan gizi ikan lele dan meningkatnya kreatifitas olahan ikan lele di Desa Cikakak.
\end{abstract}

Kata kunci-budidaya, nugget, lele

\begin{abstract}
The cultivation in Cikakak Village, Banjarharjo District is catfish farming with the Sangkuriang type. So far, the use of catfish is still limited, only sold directly to customers or marketed without processing and as daily consumption. In order to increase the creativity and economic value of catfish as a result of cultivation, a community service program was carried out with the target of $P K K$, posyandu cadres and catfish farming entrepreneurs in Cikakak Village. The community service carried out is by providing counseling on the nutritional content of catfish and training on catfish nugget processing for PKK mothers, posyandu cadres and catfish farming business actors in Cikakak Village. This service activity aims to increase the creativity of Cikakak villagers in using catfish so as to increase its economic value. The result of the dedication in Cikakak village is an increase in knowledge about the nutritional content of catfish and an increase in the creativity of catfish processing in Cikakak Village
\end{abstract}

Keyword-cultivation, nugget, catfish

\section{PENDAHULUAN}

Ikan merupakan salah satu sumber protein hewani yang diperlukan oleh tubuh. Selain protein, zat lain yang terkandung dalam ikan dan dibutuhkan oleh tubuh adalah vitamin, lemak, dan mineral. Hal tersebut menyebabkan perlunya mengkonsumsi ikan secara teratur. Selain itu, ikan merupakan sumber protein yang lebih ekonomis jika dibandingkan dengan sumber protein lain seperti daging sapi dan daging kambing(Yuniastri et al., 2020)

Salah satu ikan yang mudah untuk dibudidayakan adalah ikan lele. Kemudahan pembudidayaan lele disebabkan karena lele merupakan salah satu ikan air tawar yang dapat bertahan hidup pada tempat kritis seperti sungai, kolam ikan baik yang subur maupun yang keruh, rawa, sawah, dan tempat berlumpur yang kekurangan oksigen.

Menurut(Fitriani et al., 2019), ikan lele dapat hidup di tempat kritis tersebut disebabkan oleh alat pernafasan tambahan berupa Arborecent. Hal ini menyebabkan pembudidayaan lele dapat dilakukan di tambak air payau dengan kadar garam yang tidak terlalu tinggi. Jenis ikan lele yang sering dibudidayakan di Indonesia antara lain ikan lele jenis lokal, ikan lele jenis Dumbo, dan ikan lele jenis Sangkuriang. Akan tetapi ikan lele jenis Clarias Batrachus (Lokal) 
merupakan ikan lele yang paling sering dijumpai dan dipelihara karena dagingnya yang lezat. Berdasarkan data Departemen Perikanan dan Kelautan yang tercantum dalam Kelautan dan Perikanan dalam angka 2009, produksi ikan lele di Indonesia dalam kurun waku 5 tahun terakhir mengalami peningkatan yang cukup tinggi dibandingkan komoditi perikanan budidaya lainnya seperti nila, gurami, patin dan bandeng.

Budidaya ikan lele berkembang pesat di kalangan masyarakat karena dapat dibudidayakan di lahan dan sumber air yang terbatas dengan padat tebar tinggi. Selain itu budidayanya relatif mudah dikuasai, dibandingkan dengan gurami yang membutuhkan perawatan air yang intensif Hasil pemasaran ikan lele relatif mudah karena banyak diolah menjadi makanan yang umum dikonsumsi sehari-hari seperti pecel lele ataupun mangut lele. Modal usaha pengembangan budidaya lele juga rendah. Produksi ikan lele di Indonesia mengalami peningkatan sejak tahun 2010 hingga 2013. Pada tahun 2011 meningkat 39\% dari tahun sebelumnya, pada tahun 2012 meningkat 30\% dari tahun sebelumnya dan pada tahun 2013 meningkat sebanyak 41,8\% (Justisia \& Adi, 2016).

Ikan mengandung berbagai protein, lemak (asam lemak omega 3), vitamin (vitamin A, vitamin D, vitamin B6, vitamin B12), dan mineral (zat besi, yodium, selenium, seng, dan fluor) yang dibutuhkan oleh tubuh(Herawati et al., 2020). Berdasarkan penelitian (Ubaidillah \& Hersulistyorini, 2010) kandungan gizi ikan lele cukup tinggi yaitu protein $(17,7 \%)$, lemak $(4,8$ $\%)$, mineral $(1,2 \%)$, dan air (76\%). Keunggulan ikan lele dibandingkan dengan produk hewani lainnya adalah kaya akan leusin dan lisin dan asam lemak omega-3 dan omega-6 (Santoso et al., 2019). Leusin $\left(\mathrm{C}_{6} \mathrm{H}_{13} \mathrm{NO}_{2}\right)$ merupakan asam amino esensial yang sangat diperlukan untuk pertumbuhan anak-anak dan menjaga keseimbangan nitrogen. Leusin juga berguna untuk perombakan dan pembentukan protein otot. Sedangkan lisin merupakan salah satu dari 9 asam amino esensial yang dibutuhkan untuk pertumbuhan dan perbaikan jaringan. Lisin termasuk asam amino yang sangat penting dan dibutuhkan sekali dalam pertumbuhan dan perkembangan anak(Andri et al., 2020)

Hampir semua jenis ikan mengandung merkuri. Merkuri adalah logam berat hasil buangan dari limbah pabrik dan rumah tangga. Di dalam air, merkuri akan berubah menjadi zat yang disebut dengan metilmerkuri yang berikatan dengan protein dalam otot ikan. Mengonsumsi ikan atau makanan laut lainnya yang mengandung merkuri, maka kandungan merkuri dalam daging ikan akan masuk ke dalam tubuh. Penumpukkan merkuri dalam tubuh dalam jangka panjang dapat menyebabkan gangguan kesehatan, seperti keracunan merkuri hingga bahkan kerusakan saraf, terutama pada bayi dan anak-anak.

Ikan lele diketahui memiliki kandungan merkuri yang paling rendah dibandingkan dengan ikan lain yaitu kurang dari 0,09 ppm(Admin, 2011). Meski demikian, dianjurkan membatasi konsumsi ikan lele untuk mengurangi risiko terkena paparan merkuri. Terutama bagi wanita hamil, karena kadar merkuri yang tinggi dapat membahayakan janin. Pada umumnya, ikan lele aman untuk dikonsumsi sebanyak dua sampai tiga kali dalam satu minggu. Daging ikan lele memiliki daya simpan yang singkat sehingga perlu dilakukan pengolahan untuk menambah masa simpan ikan lele. Ikan lele sudah banyak dimanfaatkan sebagai bahan pembuatan bakso, abon, daging dan nugget (Darmadi et al., 2019). Nugget merupakan makanan berprotein tinggi yang terbuat dari daging yang mengandung protein hewani ataupun dari bijibijian yang mengandung protein nabati, nugget merupakan makanan yang populer dikalangan masyarakat karena memiliki nilai gizi yang tinggi, rasanya yang enak dan penyajiannya yang praktis. Kehidupan masyarakat moderen yang ingin serba praktis membuat nugget menjadi makanan yang biasa digunakan sebagai lauk atau selingan. Penerimaan masyarakat terhadap produk nugget saat ini semakin meningkat, hal ini dapat dilihat banyaknya produk nugget yang dijumpai dari berbagai macam bahan baku seperti nugget ayam, sapi dan ikan. Pengolahan daging ikan lele menjadi nugget diharapkan dapat menambah variasi olahan makanan ikan dan menambah masa simpan. Selama ini pemanfaatan lele masih sebatas digoreng. Beberapa konsumen tidak menyukai bau khas ikan lele yang digoreng padahal nilai gizinya cukup tinggi.

Desa Cikakak terletak di Kecamatan Banjarharjo, Kabupaten Brebes merupakan daerah yang kaya akan keanekaragaman hayati, misalnya ikan lele. Budidaya ikan lele sudah banyak 
dilakukan oleh masyarakat, terutama dengan semakin maraknya usaha warung Pecel Lele di daerah sekitar. Ikan lele sudah sejak lama menjadi salah satu komoditas perikanan yang sangat populer di kalangan masyarakat. Jenis lele yang dibudidayakan warga Desa Cikakak adalah ikan lele jenis Sangkuriang. Pembudidayaan ikan lele Sangkuriang memiliki kelebihan jika dibandingkan dengan pembudidayaan lele lain. Hal ini disebabkan pertumbuhan lele sangkuriang lebih cepat apabila dibandingkan dengan pertumbuhan lele dumbo. Jika dibandingkan dengan lele dumbo, lele sangkuriang memiliki masa pertumbuhan yang lebih cepat. Lele dengan panjang 2 hingga $3 \mathrm{~cm}$ hanya membutuhkan waktu sekitar dua puluh hari untuk mencapai panjang 5 sampai $6 \mathrm{~cm}$. Sementara lele dumbo membutuhkan waktu sekitar 30 sampai 40 hari. Pertumbuhan ini akan lebih cepat bila lele dipelihara di daerah yang panas. Suhu minimal untuk membudidayakan ikan lele sangkuriang yaitu $25^{\circ} \mathrm{C}$.

Kemampuan ikan lele sangkuriang untuk bertelur lebih tinggi jika dibandingkan dengan lele dumbo. Begitu juga dengan kemampuannya dalam menetaskan telur, yang mengungguli ikan lele dumbo sekitar 10 persen. Salah satu upaya yang dapat dilakukan untuk meningkatkan penghasilan warga Desa Cikakak terhadap hasil budidaya ikan lele adalah dengan melakukan pengolahan dahulu terhadap hasil budidaya. Jenis pengolahan yang dapat dilakukan adalah mengolah ikan lele menjadi kedalam bentuk nugget. Pemilihan nugget sebagai bahan pengolahan ikan didasarkan pada bentuk dari nugget yang dapat divariasikan dan dapat memperpanjang daya simpan dari khasiat yang dimiliki oleh ikan lele. Nugget dapat bertahan lama apabila disimpan dalam kondisi beku. Selain itu, pengolahan nugget mudah dilakukan

\section{METODE PELAKSANAAN}

Pelaksanaan program kerja pengabdian ini menggunakan metode ceramah ilmiah dan praktik langsung, terbagi atas tiga tahapan yaitu tahapan perencanaan kegiatan, tahapan pelaksanaan kegiatan, dan tahapan evaluasi kegiatan. Kegiatan yang dilakukan pada tahap perencanaan antara lain melakukan survei lapangan, merancang solusi dari permasalahan yang didapatkan, dan merancang jadwal kegiatan.

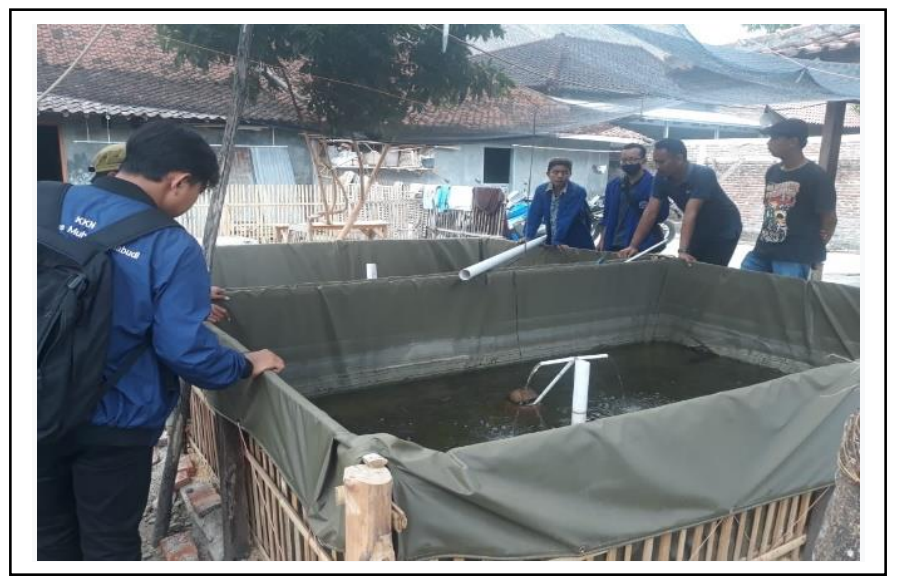

Gambar 1. Survey lapangan 
Tahapan pelaksanaan dilakukan pada bulan September 2020 kegiatan yang dilakukan yaitu melakukan sosialisasi pengembangan produk olahan ikan lele dan menjelaskan tentang kandungan gizi pada ikan lele yang akan dijadikan nugget dan pelatihan atau demonstrasi pembuatan produk olahan ikan lele menjadi nugget dengan memanfaatkan hasil budidaya ikan lele. Tahapan evaluasi, kegiatan evaluasi yang dilaksanakan adalah dengan dilakukan penilaian antusiasme warga terhadap kegiatan. Bagaimana pengetahuan masyarakat terhadap materi dan praktik yang dilakukan. Pembuatan nugget ikan lele dimulai dari proses pemfiletan daging ikan lele. Bumbu halus yang digunakan diantaranya bawang merah, bawang putih, lada atau merica bubuk dan garam. Bahan tambahan lain diantaranya tepung maizena, telur dan tepung panir. Dari 3 ekor ikan lele bisa menghasilkan daging fillet ikan lele sebanyak 250 gr. Alat-alat yang digunakan pada proses pembuatan nugget ikan lele ini antara lain blender, baskom plastik, nampan, piring, sendok, Loyang, pisau, timbangan, cetakan, dandang pengukus, kompor, wajan dan freezer. Menurut (Bakso et al., 2018) dan (Nasrullah et al., 2019) proses pembuatan nugget ditampilkan pada Gambar 2.

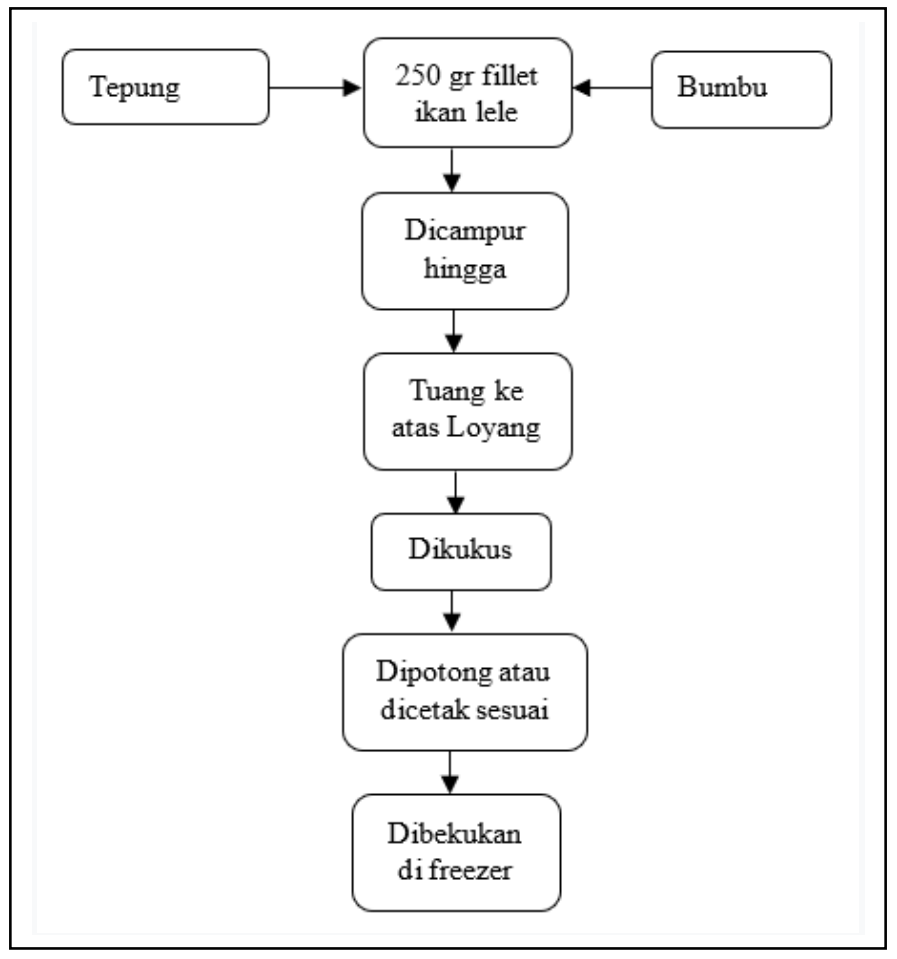

Gambar 2. Diagram alir pembuatan nugget ikan lele

Masa simpan nugget yang sudah mengalami proses pengukusan dan pembekuan cukup lama. Apabila akan dikonsumsi, nugget bisa digoreng secara langsung atau diberi bahan olesan terlebih dahulu agar bentuknya seperti nugget yang ada di pasaran. Bahan olesan yang digunakan adalah kocokan telur dan tepung panir. Nugget dicelupkan ke dalam kocokan telur dan dibalur dengan tepung panir.

\section{HASIL DAN PEMBAHASAN}

\section{Penyuluhan Pemanfaatan Pangan Lokal Lele Menjadi Olahan Nugget Lele}

Pelaksanaan kegiatan program kerja pengabdian masyarakat mengadakan penyuluhan terhadap warga Desa Cikakak tentang pengolahan yang dapat dilakukan dari hasil budidaya ikan lele sehingga hasil budidaya yang tidak langsung di jual tanpa ada pengolahan kepada pembeli. Kegiatan penyuluhan ini dilaksanakan di Balai Desa Cikakak. Penyuluhan dilaksanakan tanggal 
9 September 2020 pada jam 10.00 sampai dengan selesai. Sasaran Penyuluhan adalah ibu-ibu PKK, kader posyandu dan pembudidaya lele setempat.

Pada kegiatan penyuluhan ini, warga Desa Cikakak dijelaskan tentang kandungan gizi pada ikan lele dan menjelaskan pembuatan alternatif olahan dengan bahan dasar lele salah satunya yaitu nugget lele. Pemanfaatan lele di Desa Cikakak masih sangat terbatas. Selain dijual secara langsung ke pedagang pecel lele, ikan lele juga menjadi makanan konsumsi sehari-hari sebagai lauk. Menurut ibu-ibu yang hadir sebagai peserta pengabdian, ikan lele digoreng atau dipepes.

Tekstur daging ikan lele relatif lebih lembut dibandingkan dengan ikan lain karena kadar airnya yang cukup tinggi yaitu $76 \%$ (Harianti \& Tanberika, 2018), sehingga menyebabkan masa simpan lele yang tidak lama. Selain untuk menambah masa simpan ikan lele, pembuatan lele menjadi nugget juga untuk menambah variasi olahan lele selain digoreng atau dipepes. Beberapa orang kurang menyukai bau amis ikan lele. Sehingga pengolahan ikan lele menjadi nugget merupakan solusi yang tepat. Nugget merupakan olahan pangan dari daging yang selain tahan lama juga praktis. Olahan nugget juga disukai mulai dari anak-anak sampai orang dewasa.

Kandungan gizi ikan lele cukup tinggi. Komposisi gizi ikan lele meliputi kandungan protein $(17,7 \%)$, lemak $(4,8 \%)$, mineral (1,2\%), dan air (76\%) (Astawan, 2008) sehingga bisa dijadikan bahan pangan fungsional, sebagai makanan tambahan untuk balita dan peluang usaha yang cukup menjanjikan. Berdasarkan uji kelayakan usaha produk nugget ikan lele memberikan keuntungan. Biaya tetap yang perlu dikeluarkan dalam usaha produksi nugget diantaranya tempat produksi, instalasi listrik, pembelian alat. Perhitungan kelayakan usaha pada penelitian ini mengasumsikan biaya yang digunakan adalah biaya sendiri dan tempat usaha diasumsikan milik pribadi sehingga instalasi listrik juga diasumsikan terhubung dengan rumah induk milik pribadi.

\section{Pelatihan atau demonstrasi pembuatan olahan ikan lele menjadi nugget dengan memanfaatkan hasil budidaya ikan lele}

Setelah kegiatan penyuluhan, pelaksanaan kegiatan program kerja pengabdian masyarakat memberikan pelatihan dalam pembuatan produk olahan dari hasil budidaya ikan lele menjadi nugget. Pelaksanaan pelatihan bertempat di Balai Desa Cikakak dengan peserta ibu-ibu PKK, kader posyandu dan pembudidaya ikan lele.

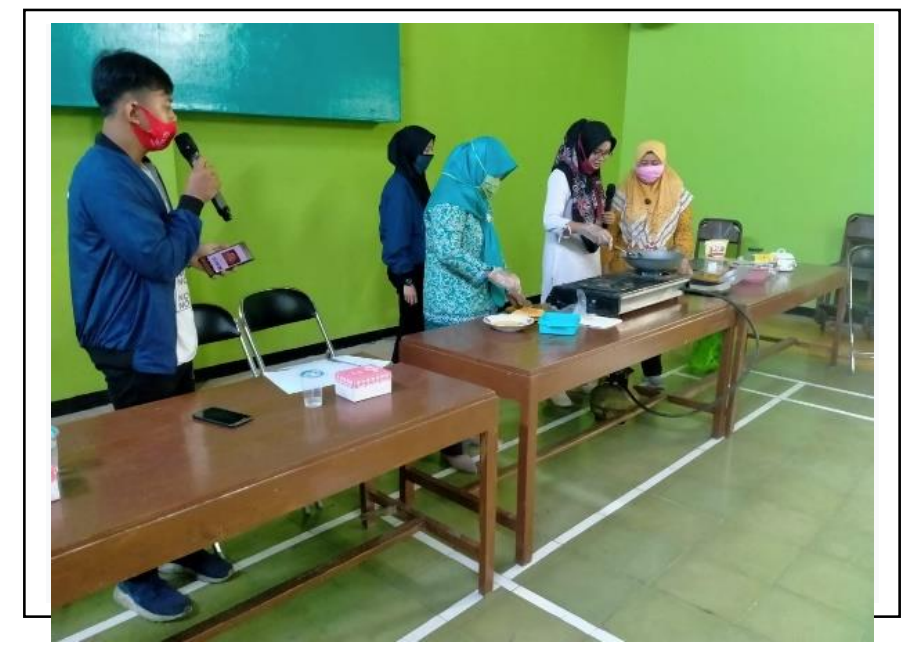

Gambar 3. Demonstrasi pembuatan nugget lele

Kegiatan pelatihan diikuti oleh 20 ibu-ibu PKK, 5 kader posyandu dan 5 pembudidaya ikan lele. Berikut adalah data responden berdasarkan umur. 
Tabel 1. IDENTITAS RESPONDEN BERDASARKAN UMUR

\begin{tabular}{ccc}
\hline Umur & N & Presentase \\
\hline $20-35$ tahun & 9 & $30 \%$ \\
\hline $36-45$ tahun & 15 & $50 \%$ \\
\hline$>45$ tahun & 6 & $20 \%$ \\
\hline Total & 30 & $100 \%$ \\
\hline *Sumber: data primer yang diolah & &
\end{tabular}

Pada saat dilakukan pelatihan pembuatan olahan ikan lele, peserta pengabdian antusias untuk mengikuti langkah-langkah bagaimana cara mengolah ikan lele menjadi nugget. Para peserta pengabdian juga diberikan kesempatan untuk mencoba mengolah ikan lele dengan menggunakan bahan-bahan yang telah disediakan. Berdasarkan uji coba hasil praktik yang dilaksanakan, para peserta pengabdian menyukai rasa nugget lele yang mempunyai cita rasa daging lele bercampur dengan bumbu.

\section{Evaluasi kegiatan}

Dari hasil pengabdian kepada masyarakat yang telah dilaksanakan, diketahui bahwa para peserta pelatihan tidak terfikirkan untuk mengolah ikan lele menjadi bentuk makanan olahan berupa nugget. Hal ini didasarkan pada tekstur dari ikan lele yang cenderung berminyak, sehingga tidak terfikirkan oleh peserta pelatihan bahwa lele dapat diolah kedalam olahan berbentuk nugget.

Setelah kegiatan pelatihan dan diberi kesempatan untuk mecoba nugget lele, tanggapan dari peserta pengabdian, $90 \%$ memberi tanggapan positif hanya saja masalah selera masing masing, dari ibu ibu PKK juga meminta untuk membagi resepnya, dan dari pembudidaya lele juga bertanggapan positif karna mereka belum pernah terfikiran untuk membuat olahan bahan dasar ikan lele hanya baru dijual belikan seperti biasa di pasaran. Peserta kader posyandu menilai nugget lele juga bisa dijadikan makanan tambahan untuk balita di kegiatan posyandu. Hasil pengetahuan peserta pengabdian juga meningkat setelah diadakan pelatihan pembuatan nugget ikan lele. Hasil peningkatan pengetahuan dapat dilihat dari Tabel 2.

Tabel 2. HASIL PRE-TEST DAN POST-TEST PESERTA PENGABDIAN

\begin{tabular}{cc}
\hline \multicolumn{2}{c}{ Nilai rata-rata $(\%)$} \\
\hline Pre test & Pro test \\
\hline 47 & 71
\end{tabular}

Pengenalan dan peningkatan pengetahuan dan ketrampilan dalam mengolah variasi produk ikan lele juga telah dilakukan oleh Suwarsito, Mustafidah dan Kartikawati di Desa Limpakuwus Kecamatan Sumbang Kabupaten Banyumas pada tahun 2018. Pada pengabdian tersebut, ikan lele yang banyak dibudidayakan di masyarakat diolah menjadi abon, kerupuk, bakso, crispy kulit ikan dan nugget ikan.

\section{KESIMPULAN}

Kegiatan penyuluhan dan pelatihan pengembangan produk olahan ikan lele menjadi nugget dengan memanfatkan hasil budidaya ikan lele yang dimiliki oleh warga berjalan dengan baik dan mendapatkan respon yang baik dari warga desa Cikakak. Pelatihan yang diberikan dapat dijadikan salah satu alternatif pengolahan makanan ikan lele selain cara yang biasa mereka lakukan yaitu digoreng dan dipepes. Alternatif yang diberikan ini menjadi salah satu cara untuk meningkatkan konsumsi ikan pada warga Cikakak, memberikan ide usaha baru dan mengatasi masalah masa simpan daging ikan lele yang singkat. Ilmu yang didapatkan dari penyuluhan dan pelatihan kepada masyarakat dapat dijadikan sebagai dasar untuk membuat olahan dari ikan lele 


\section{UCAPAN TERIMAKASIH}

Terimakasih kepada kepala Desa Cikakak, ibu-ibu PKK, kader posyandu dan pelaku usaha budidaya ikan lele Desa Cikakak yang berkenan membantu dan memfasilitasi dalam kegiatan Program Kerja Pengabdian Masyarakat

\section{DAFTAR PUSTAKA}

Admin. (2011). Ikan dengan Kandungan Merkuri yang Boleh Dimakan dan Tidak. Detik Health. https://health.detik.com/berita-detikhealth/d-1562704/ikan-dengan-kandunganmerkuri-yang-boleh-dimakan-dan-tidak

Andri, A., Harahap, R. P., \& Tribudi, Y. A. (2020). Estimasi dan Validasi Asam Amino Metionin, Lysin, dan Threonin dari Pakan Bijian Sebagai Sumber Protein Nabati. Jurnal Nutrisi Ternak Tropis, 3(1), 18-22. https://doi.org/10.21776/ub.jnt.2020.003.01.4

Bakso, P., Lele, I., Sp, C., Sari, A. M., Praseptiangga, D., Zaman, M. Z., Studi, P., Pangan, T., \& Pertanian, F. (2018). Peningkatan Produktivitas Kelompok Wanita Tani Desa Wunut, Kabupaten Klaten Melalui Pelatihan. Prosiding PKM -CSR, 1, 23-25.

Darmadi, N. M., Pandit, I. G. S., \& Sugiana, I. G. N. (2019). Pengabdian Kepada Masyarakat (PKM) Nugget Ikan (Fish Nugget). Community Services Journal (CSJ), 2(1), 18-22.

Fitriani, F., Imaniska, U., Faustiar, I. L., \& Mudjihartik, E. (2019). Pelatihan Pengolahan Nugget Lele Bagi Masyarakat Desa Gelang Sidoarjo. Abadimas Adi Buana, 03(1), 17-20. https://doi.org/https://doi.org/10.36456/abadimas.v3.i1.a1922

Harianti, R., \& Tanberika, F. S. (2018). Pemberdayaan wanita tani melalui produksi abon ikan lele. JPPM (Jurnal Pendidikan Dan Pemberdayaan Masyarakat), 5(2), 167-180. https://doi.org/https://doi.org/10.21831/jppm.v5i2.21071

Herawati, V. E., Saraswati, L. D., \& Juniarto, A. Z. (2020). Penguatan Komoditi Unggulan Masyarakat Melalui Diversifikasi Produk Olahan Ikan Di Desa Asinan Kecamatan Bawean Kabupaten Semarang. Jurnal Pasopati, 2(4), 4-9.

Justisia, S. R. W. A. H., \& Adi, A. C. (2016). Peningkatan Daya Terima dan Kadar Protein Nugget Substitusi Ikan Lele (Clarias Batrachus) dan Kacang Merah (Vigna Angularis). Media Gizi Indonesia, 11(1). https://doi.org/10.20473/mgi.v11i1.106-112

Nasrullah, R., Airlangga, U., Nasrullah, R., \& Airlangga, U. (2019). Personal Hygine Pekerja Dalam proses Produksi Nugget Ikan Lele Dumbo (Clarias Gariepinus) Di Pusat Pelatihan Mandiri Kelautan dan Perikanan (P2MKP) Karya Lestari Bali. Journal of Marine and Coastal Science, 8(February).

Santoso, S., Yanti, W. S., \& Manajemen, E. (2019). PENGOLAHAN IKAN LELE MENJADI NUGGET SEHAT DALAM BERWIRAUSAHA. Jurnal Abdikarya: Jurnal Karya Pengabdian Dosen Dan Mahasiswa, 03(03). https://doi.org/https://doi.org/10.30996/abdikarya.v3i3.3729.g2829

Ubaidillah, A., \& Hersulistyorini, W. (2010). Kadar Protein Dan Sifat Organoleptik Nugget Rajungan Dengan Substitusi Ikan Lele (Clarias Gariepinus). Jurnal Pangan Dan Gizi, l(2), 116029. https://doi.org/10.26714/jpg.1.2.2010.

Yuniastri, R., Hanafi, I., \& Wahyuni, P. R. (2020). Preferensi dan Analisis Kelayakan Usaha Produk Pudot Jatero (Jamblang Telang Rosella) Sebagai Produk Pangan Fungsional. Prosiding Seminar Nasional Hasil Penelitian Dan Pengabdian Masyarakat Dengan Tema "Kesehatan Modern Dan Tradisional." 